\title{
Open innovations as a means of increasing the competitiveness of enterprises on a global scale
}

\author{
Zuzana Rosnerova ${ }^{1, * *}$ \\ ${ }^{1}$ University of Zilina, Faculty of Operation and Economics of Transport and Communications, \\ Department of Economics, Univerzitna 1, 01026 Zilina, Slovakia
}

\begin{abstract}
Research background: Innovation is considered to be the driving force of any economy. In many cases, innovations are perceived as a means of increasing the competitiveness of companies or streamlining business processes. In cases where companies have introduced innovations into their practice, this has been reflected in their financial economy, and in many cases better financial results have been achieved.

Purpose of the article: The article deals with the issue of open innovations and addresses the degree of implementation of open innovations in companies operating on the Slovak market. The aim of the paper is to identify the state of use of the concept of open innovation. It also aims to find out whether companies applying this concept are interested in obtaining funds from public sources and which public sources are most interested in.

Methods: As part of the analysis of the state of use of open innovations in the conditions of companies operating in the Slovak economy, descriptive and comparative methods are used, on the basis of which is possible find out the interest of companies in the concept of open innovations. The results are displayed through a description and graphical display.

Findings \& Value added: Based on the findings, it can be stated that $64.34 \%$ of companies have addressed the concept of open innovation in their practice. Regarding the interest of companies in public sources of financing for open innovation, the most common sources are the European Structural Funds.
\end{abstract}

Keywords: open innovation; small and medium enterprises; competitiveness; public sources of financing

JEL Classification: $O 3 ; 031 ; O 36$

*Corresponding author: zuzana.rosnerova@fpedas.uniza.sk 


\section{Introduction}

The innovative economy and business environment are among the most important factors in the socio-economic development of any country (Swiadek and Goraczkowska, 2020). A necessary condition for the existence of a company on the market and its survival in general is a competitive advantage that is created in the business environment. This is very important for the company because it helps it to progress and also distinguishes the subject from other companies operating in the market (Janoskova and Kral, 2019; Kelic et al., 2020). Schumpeter assessed the company's ability to build competitiveness based on the impact of innovation. Schumpeter believes that companies should focus more on leveraging technological innovation to achieve a strategic competitive advantage (Schumpeter, 1950). In this way, the company would have the effect of a monopoly position in the short term, from which it can draw several benefits. However, the effect of innovation does not last indefinitely, as other companies try to imitate a competing company and the market comes into equilibrium after some time. The balance is only again disturbed when another company implements an innovation that will allow it to gain a competitive advantage over other companies in the market. Schumpeter (1950) called this process a creative destruction, in which case when something new is created, this fact causes the original rules to be abolished and new rules to be introduced. Business innovations affect the performance of the company and act as a mediator between organizational changes and the financial performance of the company, which according to the authors Durana et al. (2020) or Bailey et al. (2021) can be measured on the basis of the achieved income of the company. Mittal (2020) assesses the diversity of innovation in two respects. If technical and economic requirements dominate in the area of business interests, the company will implement the concepts of radical innovations. If it were to focus more on social concepts, the incremental effects of innovation will be monitored. According to Williams et al. (2020) is the most striking motivation for solving business innovations competitive pressure and characterizes business innovations as an effort to optimize the business processes of the company in order to build its competitiveness. In the field of optimization of production processes, according to Clark et al. (2020) an important purpose of artificial intelligence, which is equally applicable in decision-making processes, which belong to important aspects in the field of solving business innovations. Innovation can be understood as the result of activities that the company implements within its strategic framework, while these activities are initiated by agents of change. As a result, it may be new processes, a new way of organizing, new services or new products (Janoskova and Kral, 2019). In order for a company to achieve innovation, it is necessary to meet a number of different conditions (Zauskova et al., 2020). The first author to classify innovations was Schumpeter, who selected innovations as follows:

- new products, resp. existing products produced in a new quality,

- implementation of a new production process or production method,

- use of new raw materials and semi-finished products in production,

- gaining a new market (Schumpeter, 1934).

The current period, characterized by dynamic development, brings with it a new dimension of innovation. It is the concept of open innovations, which consist in the implementation of innovation activities using the cooperation of another entity.

The question of open innovations is connected with the author Henry Chesbrought, who defines these innovations as a purposeful flow of knowledge inwards, resp. outside the company, whose task is to accelerate innovation within the company, or helps to create markets that will allow external use of innovation as well as access to global markets (Chesbrough, 2003). Von Hipper and Von Krogh (2005) also emphasize the greater openness of companies in their innovation activities, who in their publications emphasize the benefits resulting from the involvement of customers and suppliers in the company's 
innovation process. In their publication, we find statements that it is more advantageous for companies if they do not carry out their innovation activities entirely on their own, but other entities are also involved in them during the various phases of their implementation. This method of implementation can also be applied in the opposite position, when the company offers its innovative capacities to other entities as well. However, many companies are sceptical of open innovation and prefer closed innovation. Based on what model of innovation companies perform, we distinguish between open or closed innovations. Closed innovations are carried out exclusively in the company's internal environment without cooperation with external entities. When a company implements closed innovations, the potential of managers is used, resp. management of the company and also the potential of the company employees. Closed innovations are successfully implemented especially in the environment of medium and large companies. As businesses now approach the interconnectedness of business processes, open innovation comes into use. Open innovations are characterized by mutual inter-company cooperation in the implementation of innovations. These innovations combine ideas and experiences from multiple sources. Open innovations are often implemented in different systems, which helps to accelerate the innovative activities of companies. During the implementation of innovation activities, several entities are involved in this process, including other companies, high schools or universities, they may also include research and development centers, but in some cases also artists or freelancers (Cortonesi et al., 2019). The application of the use of open innovations in the business environment is conditioned by the fact that innovative projects should have lower fixed costs, should be characterized by flexibility in changing consumer requirements and the requirements of the socio-economic environment (Kovac, 2011). The following figure shows the difference between closed and open innovation activities of a company.

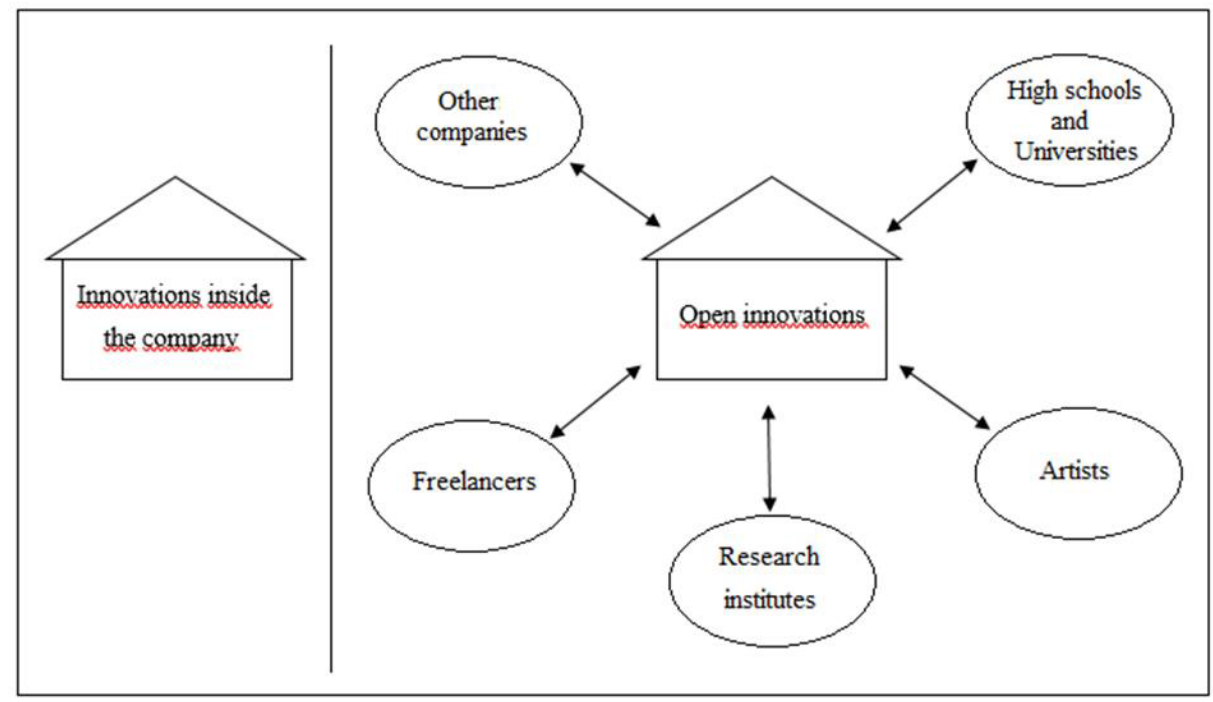

Figure 1. The difference between closed and open innovation activities of the company.

Source: author's processing (2021)

The problematic area of open innovations is their financing. Businesses can finance these activities through equity, on the other hand, there is the possibility of using public sources of financing. The use of public sources of funding can thus be considered a significant advantage. It is questionable how many companies will actually apply for such a financing option. The theory shows that some innovations are difficult to finance in 
conventional ways (i.e., bank loans, investor input, etc.) even in countries where the capital market is sufficiently developed. Therefore, under certain conditions, it is appropriate to support innovative companies with some form of public support.

\section{Methods - Analysis of the position of open innovations in the conditions of the Slovak republic}

The aim of the article is to find out whether Slovak companies use the concept of open innovations.

The paper hypothesis was determined on the basis of two assumptions:

Hypothesis 1: At least $60 \%$ of companies have experience in solving the concept of open innovation.

Hypothesis 2: $3 / 4$ of Slovak companies that apply open innovations are mainly interested in public financial support through the European Structural Funds.

The research was carried out through a questionnaire survey, which was attended by 385 companies operating in the Slovak Republic.

Based on the survey, it was found that 286 participating companies, which represents $91 \%$ of participating companies, already have experience with innovation, i.e., addressed innovation and 99 of the companies contacted, i.e., 9\%, have not yet implemented or addressed innovation. The results are shown in the following graph.

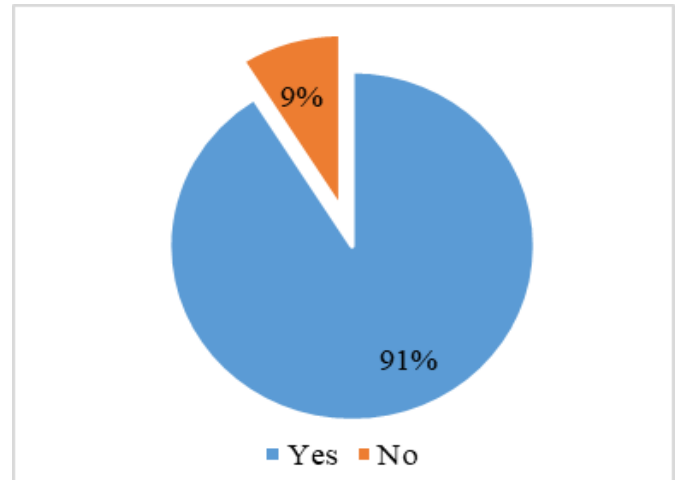

Figure 2. Division of companies in terms of experience with innovation activities

Source: author's processing (2021)

Another object of interest was to find out how many companies with experience in innovation have dealt with the concept of open innovation. In this case, I used 286 respondents. It is clear from the results that of the companies that already have experience with innovation, $64.34 \%$ of the participating companies have experience with open innovation. In absolute terms, there are 184 business entities. The rest of the companies, ie. $35.66 \%$ of the addressed companies have no experience with open innovation, which in absolute terms represents 102 companies. The results are shown in Figure 3. 


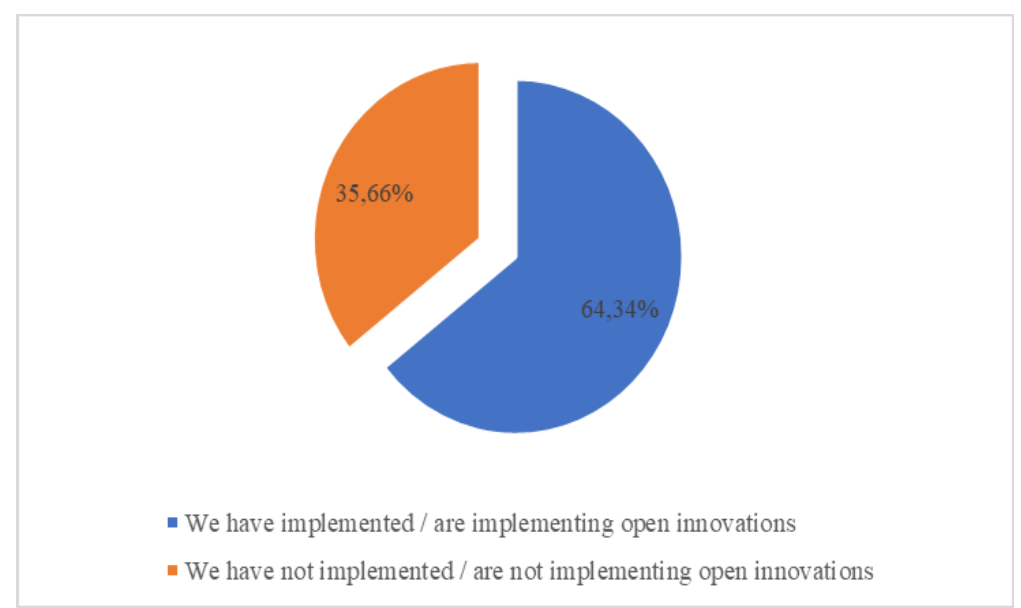

Figure 3. Division of enterprises in terms of experience with open innovation

Source: author's processing (2021)

Another of my target areas in the case of open innovations was to find out what public sources for financing open innovations companies operating on the Slovak market are most interested in. The companies selected from the sources: The European Structural Funds, Horizon 2020, LIFE, COSME, VEGA projects and were also offered another option. The results for this area of interest are shown in the following figure.

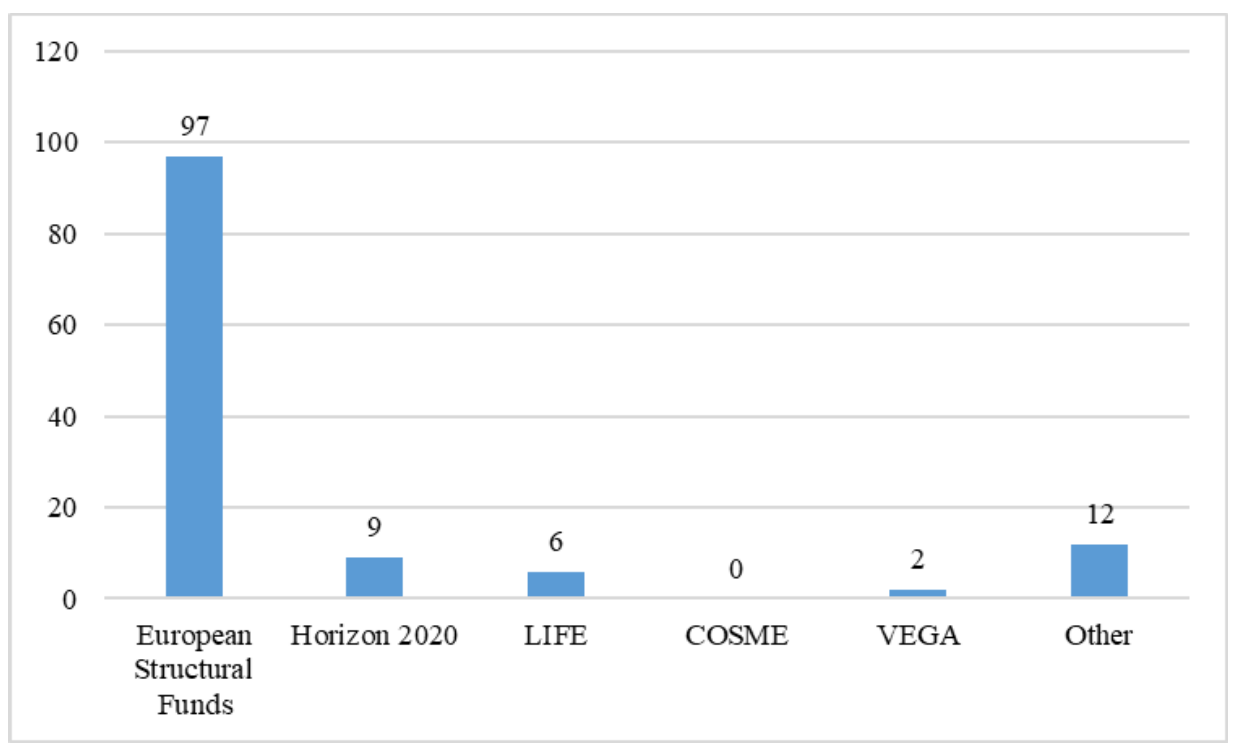

Figure 4. Business interest in public sources of finance in the case of open innovation

Source: author's processing (2021) 
I have also addressed the question of how companies assess the benefits of open innovation. The findings are presented in the following table.

Table 1. Benefits of open innovation for businesses

\begin{tabular}{|l|l|}
\hline \multirow{4}{*}{\begin{tabular}{c} 
Benefits of open innovation for $\begin{array}{c}\text { businesses } \\
\text { bus }\end{array}$ \\
\cline { 2 - 2 }
\end{tabular}} & Environmental Protection \\
\cline { 2 - 2 } & Access to new markets \\
\cline { 2 - 2 } & Added value of the final product \\
\cline { 2 - 2 } & Company image \\
\cline { 2 - 2 } & Leading the way over the competition \\
\cline { 2 - 2 } & Increasing productivity and technical capacity \\
\cline { 2 - 2 } & Attracting investors \\
\cline { 2 - 2 } & Other (energy saving, feeling satisfied) \\
\hline
\end{tabular}

Source: author's processing (2021)

\section{Results and discussion}

The aim of the presented paper was to find out the interest of Slovak companies in the concept of open innovations. I worked with two hypotheses. One assumed that at least $60 \%$ of companies that have experience with innovation also used the concept of open innovation. The second hypothesis was that $3 / 4$ companies, which represent $75 \%$ in percentage terms, use the Structural Funds among public sources to finance open-ended innovations. The advantage of open innovations is the mutual cooperation between companies, on the basis of which it is possible to achieve more significant effects than if the company covered the entire process of innovation itself. 385 companies operating on the Slovak market were involved in the survey. Of the total number of respondents, $91 \%$ said that they already had experience with innovation. The remaining $9 \%$ of the addressed companies have not yet solved the innovation. In further research, we only asked companies that have already addressed innovations, i.e. only 286 companies were selected for this area of interest. From this group of companies, I needed to find out if they have experience in solving open innovations in their practice. Of these, it was stated that $64.34 \%$ have experience with open innovations and thus have already implemented such an innovation, resp. it is currently being implemented. In absolute terms, there are 184 companies with such experience. The remaining part, $35.66 \%$ of the surveyed companies, have not yet introduced this type of innovation, and in absolute terms, there are 102 companies. Another object of interest was to find out whether companies are also interested in public resources within the financing, which include the European Structural Funds, the Horizon 2020 program, LIGE, COSME, VEGY or other public financing programs. Among the 184 companies that solved, resp. addressing open innovation, 126 companies stated that they also used public sources of funding for this purpose. The remaining part, 58 companies, did not apply for financial support from public sources. The survey shows that the most common form of support for public funding is the European Structural Funds, which in their responses identified 97 companies that used public funding. The following results were recorded: Horizon 2020 was used by 9 companies; the LIFE 6 business program; COSME no business; VEGA projects were used by 2 companies and we also included in the selection the option "Other", which marked 12 companies. From the above results, it can be stated that the first hypothesis was confirmed, because it turned out that up to $64.34 \%$ of the addressed companies addressed the issue of open innovation. The second hypothesis addressed the issue of interest in public sources of funding for open innovation, and I assumed that $3 / 4$ companies are most interested in the European Structural Funds as a public source of support for funding. The results show that $76.98 \%$ of companies with 
experience in open-ended innovation have used / are using the European Structural Funds as an external source of funding. This hypothesis was thus also confirmed, as the assumption was made by $3 / 4$ enterprises, which represented $75 \%$. The results of the survey reached this limit, even exceeding it by a minimum - $1.98 \%$, to the limit of $76.98 \%$. Based on the findings, it can be stated that companies operating on the Slovak market have a positive tendency to the concept of open innovations. According to Gavurova et al. (2011), business innovations are characterized by high economic value, which leads to their analysis from a macroeconomic point of view. Competition is also very important, which is an important determinant for the implementation of innovation not only nationally but also internationally, and it is through competition that companies are driven to act towards sustainable business (Mura, 2020). One of such possibilities is the use of open innovations, which can significantly help the company in building its competitiveness. A great advantage is their financing, which is possible not only from their own resources, but also from public sources, while the research showed that Slovak companies significantly use this form for their financing. I was also interested in the benefits that open innovation brings from a business perspective. The most common benefits according to companies are environmental protection, access to new markets, added value of the final product, improving the company's image, competitive position, increasing productivity and technical capacity, attracting investors. The companies were also offered the option of being labelled "Other", where they expressed their views on the benefits of these innovations. Most often it was energy saving or a feeling of satisfaction.

\section{Conclusion}

Innovation is the driving force of any economy, as it sets competition between businesses in motion. Attention is drawn to the concept of open innovation; through which it is possible to strengthen the position of companies through mutual cooperation. The aim of the paper was to find out what is the interest of Slovak companies in open innovations. Through the results of the research, it can be stated that the vast majority of Slovak companies are in favour of this type of innovation and for this purpose they also approach the use of public resources for their financing.

\section{Acknowledgements}

The paper is an output of the science project VEGA 1/0619/20 Fundamental research of quantitative and qualitative determinants of enterprise innovation potential and innovation performance in relation to increasing its competitiveness.

\section{References}

1. Bailey, L., Grupac, M., and Sosedova, J. (2021). COVID-19 Vaccine Risk Beliefs, Perceptions, Attitudes, and Intentions. Review of Contemporary Philosophy, 20, 81-92

2. Clark, A., Zhuravleva, N. A., Siekelova, A, \& Frajtova Michalikova, K. (2020). Industrial Artificial Intelligence, Business Process Optimization, and Big Data-driven Decision-Making Processes in Cyber-Physical System-based Smart Factories. Journal of Self-Governance and Management Economics, 8(2), 28-34.

3. Cortonesi, P., Cahen, F. R. \& Borini, F. M. (2019). Reverse open innovation: open innovation as a relevant factor for reverse innovation. International Journal of Innovation and Learning, 26(1), 94-114. 
4. Durana, P., Valaskova, K., Vagner, L., Zadnanova, S., Podhorska, I. \& Siekelova, A. (2020). Disclosure of Strategic Managers' Factotum: Behavioral Incentives of Innovative Business. International Journal of Financial Studies, 8(1), 17.

5. Gavurova, B., Belas, J., Valaskova, Rigelsky, M. \& Ivankova, V. (2021). Relations between infrastructure innovations and tourism spending in developed countries: A macroeconomic perspective. Technological and Economic Development of Economy, 27(5), 1072-1094.

6. Von Hippel, E. \& Von Krogh, G. (2003). Open Source Software and the "PrivateCollective" Innovation Model: Issues for Organization Science. Organization Science. 14(2), 1217-1241.

7. Chesbrough, H. (2003). Open Innovation: The New Imperative for Creating \& Profiting from Technology. Boston: Harvard Business School Press.

8. Janoskova, K. \& Kral, P. (2019). An in-depth analysis of the summary innovation index in the V4 countries. Journal of competitiveness, 11(2), 68.

9. Kelic, I., Erceg, A. \& Candrlic Dankos, I. (2020). Increasing tourism competitiveness: Connecting Blue and Green Croatia. Journal of Tourism and Services, 20(11), 132149.

10. Kovac, M. (2011). Vyvoj inovacnych modelov. TUKE.

11. Mittal, H. (2020). How does the institutional context of an emerging economy shape the innovation trajectory of different types of firms? A case study of India. Ekonomicko-manazerske spektrum, 14(2), 36-51.

12. Mura, L. (2020). Innovations and Marketing Management of Family Businesses: Results of Empirical Study. International Journal of Entrepreneurial Knowledge, 8(2), 56-66.

13. Schumpeter, J. (1934). The Theory of Economic Development. Cambridge. Harvard University Press.

14. Schumpeter, J. (1950). Capitalism, Socialism, and Democracy. New York: Harper \& Row Publishers.

15. Swiadek, A. \& Gorączkowska, J. (2020). The institutional support for an innovation cooperation in industry: the case of Poland. Equilibrium. Quarterly Journal of Economics and Economic Policy, 15(4), 811-831.

16. Williams, A., Suler, P. \& Vrbka, J. (2020). Business Process Optimization, Cognitive Decision-Making Algorithms, and Artificial Intelligence Data-driven Internet of Things Systems in Sustainable Smart Manufacturing. Journal of Self-Governance and Management Economics, 8(4), 39-48.

17. Zauskova, A., Lyakina, M., Tretyak, V. \& Miklencicova, R. (2020). Application of artificial neural networks to cost factors stimulating innovation - The case of Slovakia. Ekonomicko-manazerske spektrum, 14(1), 97-105. 